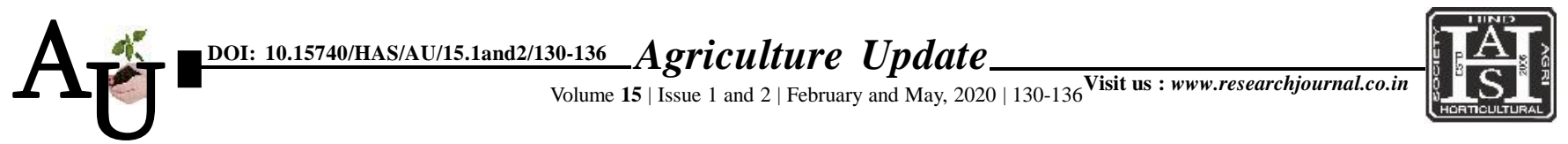

ISSN-0973-1520

\title{
A CAsE Studv: Impact of lockdown on agriculture and allied sector in Washim district
}

\author{
S.K. Deshmukh
}

Article Chronicle:

Received :

01.04.2020;

Accepted :

29.04.2020

Key Words:

Impact, Best emerging practices, Initiatives

of KVK, Skill

SUMMARY : Study on Impact of COVID-19 lockdown on agriculture and allied sector,best emerging practices in production, processing,value addition and marketing and initiatives of Krishi Vigyan Kendra to update farmer in these circumstances was carried out by KVK in the district.The data on impact of COVID-19 on agriculture and allied sector reveals that 50 per cent Rabi crops harvesting delayed due to non-availability of labour and field operations were costilier.34 per cent farmers faced problem of sale of farm produce, turmeric crop harvesting losses upto 75 per cent mostly small and marginal farmers were affected due to lockdown. Fruit and vegetable growers has to succumb 85 per cent losses during sale, storage and marketing due to district boundaries blocking. Marketing problem has shown the another way of direct marketing through personal contact or use social media group. Similarly due to lockdown best agriculture practices has emerged in the field of production, processing, marketing and supply chain management. 30 per cent losses in dairy and 87 per cent losses in poultry farming enterprise has been indicated in the study.

How to cite this article : Deshmukh, S.K. (2020). Impact of lockdown on agriculture and allied sector in Washim district. Agric. Update, 15(1 and 2): 130-136; DOI : 10.15740/HAS/AU/15.1and2/130-136. Copyright@ 2020: Hind Agri-Horticultural Society.

development 